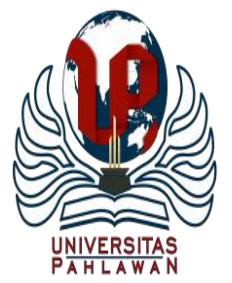

Jurnal Basicedu Volume 4 Nomor 4 Tahun 2020 Halaman 1423 - 1428

JURNAL BASICEDU

Research \& Learning in Elementary Education https://jbasic.org/index.php/basicedu

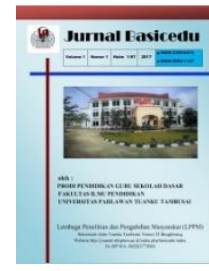

\title{
Improving Teachers 'Abilities in Video Based Learning by Using Microsoft Powerpoint Application Through Workshop
}

\author{
Mega Adyna Movitaria ${ }^{1}$, Yosi Shandra ${ }^{2}$ \\ Institut Agama Islam (IAI) Sumbar Pariaman, Indonesia ${ }^{1}$ \\ SMAN 10 Padang $^{2}$ \\ E-mail : megaadyna.iaisumbar@gmail.com ${ }^{1}$ yosishandra@gmail.com ${ }^{2}$
}

\begin{abstract}
This research was conducted based on the fact that the low ability of teachers in making learning media had an effect on school quality. The purpose of this study was to determine the increase in the ability of teachers to make instructional videos based on the Microsoft PowerPoint application on Teacher Elementary school workshops. This research is a descriptive quantitative research with a population of 25 people. The data collection technique in this study uses a questionnaire method. The results showed that the workshop for making instructional media could improve the ability of teachers to create and use video learning media based on the Microsoft PowerPoint application. Researchers suggest that Microsoft PowerPoint can be used by teachers in making instructional videos.
\end{abstract}

Keywords: microsoft power point, video, workshop

\begin{abstract}
Abstrak
Penelitian ini dilatarbelakangi oleh kenyataan yang terjadi di lapangan bahwa rendahnya kemampuan guru dalam pembuatan media pembelajaran yang dapat memberi pengaruh terhadap kualitas sekolah. Tujuan penelitian ini untuk mengukur, mengetahui gambaran dan meningkatkan kemampuan guru dalam pembuatan media pembelajaran dengan video berbasis aplikasi Ms powerpoint pada guru SD melalui kegiatan workshop. Jenis penelitian adalah deskriptif kuantitatif dengan jumlah populasi 25 orang. Teknik pengumpulan data dalam penelitian ini menggunakan metode kuisioner. Hasil penelitian menunjukkan bahwa dengan diterapkannya workshop pembuatan media pembelajaran dapat meningkatkan kemampuan guru dalam membuat dan menggunakan media pembelajaran video berbasis aplikasi Ms powerpoint. Peneliti menyarankan bahwa media pembelajaran video berbasis aplikasi Ms. Powerpoint dapat digunakan guru dalam pembuatan media pembelajaran.
\end{abstract}

Kata kunci: microsoft powerpoint, video, workshop

Copyright (c) 2020 Mega Adyna Movitaria, Yosi Shandra

$\triangle$ Corresponding author

Address : Pariaman

ISSN 2580-3735 (Media Cetak)

Email : megaadyna.iaisumbar@gmail.com

ISSN 2580-1147 (Media Online)

Phone : 082174317788

DOI: https://doi.org/10.31004/basicedu.v4i4.557 
1424 Improving Teachers 'Abilities In Video Based Learning By Using Microsoft Powerpoint Application Through Workshop - Mega Adyna Movitaria, Yosi Shandra

DOI: https://doi.org/10.31004/basicedu.v4i4.557

\section{INTRODUCTION}

Many countries monitor the learning of their students in order to prepare themselves for technological challenges. Assessment and evaluation as well as appropriate incentives can motivate students to learn better, motivate teachers to teach more effectively. It also motivates schools to create a more supportive and productive environment. A future education management task. Arsyad, (2015) states that education is multidisciplinary and interdisciplinary as well as cross disciplines of knowledge. Over time, changes occur in human behavior. The development of human life is increasingly diverse, such as the rapid development of technology and science.The rapid development of technology and science makes human resources (HR) must be ready to face it. Readiness must require skills and knowledge. Human resources must be able to adapt quickly to development itself, as well as developments in the world of education. Education is a human effort to cultivate and develop its potential both physically and spiritually in accordance with the values that exist in society and culture.

Based on the educational technology approach, teaching media has become an attraction for the world of education. The media does not only function as a tool, but also as a channel for educational messages. Thus the teacher should be able to use the media as a tool. Teachers should not be seen as the only source when learning because other learning resources such as: textbooks, nature environment, printed mass media, and electronic mass media also play a role in the learning process.

One of the media that is often used is the use of Microsoft PowerPoint media. Microsoft Powerpoint is a type of computer program incorporated in Microsoft Office that is used for presentations. As stated by Carvalho et al., (2016), it is used for presentation purposes, teaching, and for making simple animations. Microsoft PowerPoint has several features, namely adding audio, video, images and animation in a presentation so that the presentation becomes more interesting and lively.

Based on observations, especially among teachers of subjects, SD Padang City, it was found that the learning media that was applied still used the module book as a learning medium in elementary school subjects. In the learning process, the teacher explains and reads the material presented, explaining more only using textbooks without visualizing in class such as using PowerPoint. This is because the existing facilities are not fully utilized.

The objectives of this study are: (1) measuring the ability of teachers in making learning media with videos based on the Ms PowerPoint application through workshops, (2) knowing the description of the teacher's ability in making learning media with videos based on the Ms PowerPoint application through workshops, (3) Improve the ability of teachers in making learning media with videos based on the Ms PowerPoint application through workshops.

Workshop activities have often been carried out by various groups in various fields. Workshop 
1425 Improving Teachers 'Abilities In Video Based Learning By Using Microsoft Powerpoint Application Through Workshop - Mega Adyna Movitaria, Yosi Shandra

DOI: https://doi.org/10.31004/basicedu.v4i4.557

activities are indeed useful, so many parties organize these activities. The purpose of the workshop is to obtain information through direct experience and convey information to one another. In addition, the workshop also aims to develop the knowledge, understanding and skills of the targets. The object is a person or a group of people. The goal is to provide understanding, knowledge, and skills to targets according to their respective needs. The process is learning and practicing topics according to procedures so that they become habits. The results can be seen immediately because they practice right away. So that there are possible changes created after participating in the training event.

Risnawati et al., (2018) define learning media as a messenger technology that can be used for learning purposes, learning media is a physical means to deliver subject matter. Arsyad (2015) states that the word media comes from Latin and is the plural form of the word "medium" which literally means "middle" or "intermediary". Risnawati et al., (2018) also explained that the media is a component of communication, namely as a messenger from the communicator.

In addition, video is one of the audio-visual media that combines several human senses. Students not only listen to what the teacher explains but also see the facts presented by the teacher in the media. Arsyad (2015) states that approximately $90 \%$ of a person's learning outcomes are obtained through the sense of sight, $5 \%$ are obtained through the sense of hearing, and $5 \%$ with other senses. Microsoft PowerPoint is a type of computer program incorporated in
Microsoft Office that is used for presentations for public purposes. By using Microsoft Powerpoint, the presentation of a discussion topic can be designed as smart as possible to attract public attention (Darudiato \& Wibowo, 2013). Carvalho et al., (2016) states that PowerPoint is an application for composing presentations that is very popular and widely used by various groups such as professionals, academics, practitioners, and beginners. Microsoft PowerPoint is an application program in the form of text, tables, charts, diagrams and so on (Wilson \& Wilson, 2015).

Animation is a form of moving visuals that can be used to explain subject matter that is difficult to convey conventionally integrated into other media such as videos, presentations, or as separate teaching materials (Setiawan \& Ulhaq, 2018). According to Harsadi (2015) animation is the process of creating motion effects or shape change effects that occur over time. Animation can be in the form of moving an object from one place to another, changing its color, or changing its shape (which is called "morphing").

Some literature states that workshops are job training, which includes theory and practice in one integrated activity. Workshop or training if interpreted in Indonesian means 'pelatihan'. With such a definition it is very clear that we will actually practice. The "learning by doing" workshop or training is guided by trainers and participants actually practicing what is being taught. 
1426 Improving Teachers 'Abilities In Video Based Learning By Using Microsoft Powerpoint Application Through Workshop - Mega Adyna Movitaria, Yosi Shandra

DOI: https://doi.org/10.31004/basicedu.v4i4.557

\section{METHOD}

The method used in this research is descriptive analytic through action, namely studies that are used to collect data, describe, process, analyze, and conclude data in order to obtain a systematic data description. The research design used in this study was a survey method. The population in this study were all elementary school teachers in the city of Padang. In this study the researcher did not discuss further about the sample, because this study used a population study, namely the total number of Economics teachers in the city of Padang, as many as 25 people. In this study, a structured questionnaire was used with a total of 17 questions.

\section{RESULT AND DISCUSSION}

From the results of the research on media making workshops, the authors analyzed whether the implementation of the media-making workshop could improve the teacher's ability to use learning media, especially the elementary school teacher in Padang. The following is the data obtained from the results of the first cycle and the second cycle.

Based on the results of research for two cycles that aim to improve the ability of elementary school teachers to use learning media in Padang City, it can be seen that the implementation of the first and second cycles has shown that with the implementation of the Microsoft PowerPoint application-based video making workshop, teachers have used more interesting media. In addition, when using media, the teacher has involved a lot of children in learning. Then the researchers conducted a workshop on making media for teachers. At the end of the activity, the researcher evaluates the activity. Based on this, it is concluded that there has been an increase in the ability of teachers to use learning media in Elementary School Padang City. This can be seen from the increase in the average value of the workshop for making media in cycle 1 and cycle 2 which is presented in table 1 below.

Table 1. Hypothesis Testing of the Effect of Animation-Based Powerpoint Media on Student Learning Motivation

\begin{tabular}{|l|c|c|c|c|}
\hline \multirow{2}{*}{ Aspect } & \multicolumn{3}{|c|}{ Percentage } \\
\cline { 2 - 5 } & Cycle I & $\begin{array}{c}\text { Inter- } \\
\text { pretation }\end{array}$ & Cycle II & $\begin{array}{c}\text { Inter- } \\
\text { pretation }\end{array}$ \\
\hline $\begin{array}{l}\text { Microsoft } \\
\begin{array}{l}\text { PowerPoint } \\
\text { based video } \\
\text { creation }\end{array}\end{array}$ & 59,58 & Poor & 73,75 & Good \\
\hline
\end{tabular}

The implementation of the workshop on making PowerPoint-based learning videos improves the ability of teachers to use learning media because with this workshop the teacher becomes motivated to use various learning media that can support children's success in learning.The significant increase in the use of instructional media between before and after the workshop was also due to the increased understanding of teachers about the importance of a medium in learning. This makes teachers choose and use learning media better. One of the media that is often used in learning is video. Microsoft PowerPoint is a Microsoft Office application program that is useful for making presentations in the form of slides. This application is usually used for presentation purposes, teaching, and for making simple animations. Microsoft PowerPoint has several 
1427 Improving Teachers 'Abilities In Video Based Learning By Using Microsoft Powerpoint Application Through Workshop - Mega Adyna Movitaria, Yosi Shandra

DOI: https://doi.org/10.31004/basicedu.v4i4.557

features, namely adding audio, video, images and animation in a presentation so that the presentation becomes more interesting and lively.

The results obtained in this study reveal that the truth of the opinions expressed by experts who state that learning media can be used as a pattern of choice. This means that teachers can choose learning media that is in accordance with the material and which is efficient to achieve their educational goals. In addition, these results are in line with the theory according to Purwanto et al., (2016) that the form of learning which is packaged in the form of a video is very good to be used to create conditions that resemble the actual situation. If this media is used appropriately by providing videos that inspire feelings, attitude learning can be done using video-based learning media.

Based on the foregoing, it can be emphasized that teachers who teach using alternative video media based on the Microsoft PowerPoint application can increase student motivation and learning outcomes compared to teachers who do not use video-based Microsoft PowerPoint media.

\section{CONCLUSION}

After the data were analyzed, it could be concluded that: (1) The media making workshop could improve the teacher's ability to use learning media, (2) The process of increasing the ability of teachers was marked by an increase in their motivation to make improvements in learning. This is very evident in the implementation of workshop activities where the teacher is more enthusiastic in understanding the workshop material and also during the simulation and practice of making learning media, (3) The magnitude of the increase in the ability of teachers to use learning media after the implementation of the media making workshop in cycle I has an average value. 57.77 with a percentage of $59.58 \%$ in the poor category. In cycle II, the average teacher's ability to use learning media increased to 77.10 with a percentage of $73.75 \%$ in the good category.

\section{REFERENCES}

Arsyad. (2015). Media Pembelajaran. Kharisma Putra Utama Offset.

Carvalho, F. S. R., Chaves, F. N., Soares, E. C. S., Pereira, K. M. A., Ribeiro, T. R., Fonteles, C. S. R., \& Costa, F. W. G. (2016). Educational utilization of microsoft powerpoint for oral and maxillofacial cancer presentations. Asian Pacific Journal of Cancer Prevention. https://doi.org/10.7314/APJCP.2016.17.4.233 7

Darudiato, S., \& Wibowo, K. I. (2013). Binusmaya sebagai Sumber Materi dalam Pembelajaran Berbasis E-Learning. ComTech. Binus University, 4(2).

Harsadi, P. (2015). Bahan Ajar Kurikulum 2013. Sinar Nusantara.

Purwanto, W., W, E. T. D. R. W., \& Hariyono. (2016). Penggunaan Model Problem Based Learning dengan Media Powerpoint untuk Meningkatkan Minat Belajar Siswa. Jurnal Pendidikan: Teori, Penelitian, Dan Pengembangan. Universitas Negeri Malang, 1(9), 1700-1705.

Risnawati, Amir, Z., \& Sari, N. (2018). The development of learning media based on visual, auditory, and kinesthetic (VAK) approach to facilitate students' mathematical understanding ability. Journal of Physics: Conference

Series. https://doi.org/10.1088/17426596/1028/1/012129 
1428 Improving Teachers 'Abilities In Video Based Learning By Using Microsoft Powerpoint Application Through Workshop - Mega Adyna Movitaria, Yosi Shandra

DOI: https://doi.org/10.31004/basicedu.v4i4.557

Setiawan, A. P., \& Ulhaq, M. M. Z. (2018).

Animation. Simulasi Digital.

Wilson, K., \& Wilson, K. (2015). PowerPoint 2013. In Everyday Computing with Windows 8.1. https://doi.org/10.1007/978-1-48420805-2_23 